\title{
LEGAL FRAMEWORK ON THE CONSERVATION ISSUE OF PULAU KUKUP NATIONAL PARK IN JOHOR, MALAYSIA
}

\author{
LOH ING $\mathrm{HOE}^{1}$ AND CHONG JU LIAN²*
}

${ }^{I}$ School of Business and Management, Royal Melbourne Institute of Technology University, Vietnam, Handi Resco Building, 521 Kim Ma, Ba Dinh District, Hanoi, Vietnam. ${ }^{2}$ Faculty of Science and Marine Environment \& Institute of Tropical Biodiversity and Sustainable Development, Universiti Malaysia Terengganu, 21030 Kuala Nerus, Terengganu, Malaysia.

*Corresponding author: julian@umt.edu.my

Submitted final draft: 74 September 2020 Accepted: 5 September 2020

http://doi.org/10.46754/jssm.2021.07.009

\begin{abstract}
The Ramsar Convention came into force on 21 December 1975, and Malaysia ratified the convention in 1994. As a party to the convention, Malaysia has shown its commitment by promoting seven Ramsar sites. Although the Ramsar sites have experienced human intervention and degradation over time, legislation in Malaysia has helped to promote the sustainable development of wetlands in Malaysia. In this paper, a critical analysis of the role of law in protecting and conserving Pulau Kukup Johor National Park as one of the Ramsar sites in Malaysia was conducted based on documents and newspaperreports analysis. In addition, the prohibition of environmental impact assessment (EIA) to be conducted on any Ramsar site in Malaysia is also discussed. Results reveal the importance of legislation to conserve and protect wetlands in Malaysia.
\end{abstract}

Keywords: Ramsar Convention, wetlands, sustainable, development, legislation.

\section{Introduction}

OThe Ramsar Convention on Wetlands, the most important international initiative for wetland protection, is a treaty adopted in 1971 with the objective of recognizing the importance of wetlands and promoting their conservation (Reis et al., 2017). Under Article 1 of the Convention, wetland is defined as areas of marsh, fen, peatland or water, whether natural or artificial, permanent or temporary, with water that is static or flowing, fresh, brackish or salt, including areas of marine water, the depth of which at low tide does not exceed 6 meters. Wetlands are highly productive and biodiverse ecosystems (Keddy et al., 2009). They provide many ecosystem services, including water purification, buffering of runoff and river discharge, production of food and fiber, and ecotourism (Keddy, 2010). Wetland ecosystems are important from conservation and sustainable management viewpoints due to their rich flora and fauna diversity. Tangible and intangible diverse resources and products of wetlands function, such as fodder, protein source (fishes, mussels etc), fuelwood, nontimber forest products, ecotourism, and flood control, have historically provided a source of income and livelihood for humans (Lamsal et al., 2017). Wetlands remain a source of sustenance for local populations, especially in developing countries, and are highly valued in many traditional societies and cultures (Gopal, 2013).

Despite the ecosystem services they provide, wetlands have been lost, degraded, or strongly modified worldwide (Reis et al., 2017). Owing to their high productivity, fertile soils, and importance for provision of water, many of the world's wetlands have historically been occupied and intensively utilized by humans (Maltby \& Acreman, 2011). The reported longterm loss of natural wetlands averages between $54 \%$ to $57 \%$ and reaching up to $90 \%$ in some regions of the world (Junk et al., 2013). As was shown by Davidson in a compilation of 169 reports of historical loss of wetlands, the extent of inland wetlands declined by $69 \%$ to $75 \%$ in the 20th century, whereas coastal wetlands declined $62 \%$ to $63 \%$ (Reis et al., 2017). In fact, more than $50 \%$ of the world's wetlands have been altered, degraded or lost in the last 150 years (O’Connell, 2003). 


\section{Human Intervention}

There is a strong association between wetland distribution in the landscape and human occupation, with the most significant threats to wetlands being associated with direct or indirect human use of these areas (Gibbs, 2011). In developing countries, where food security and poverty reduction are higher priorities than environmental protection, wetland conservation is difficult if local communities do not understand the value of wetlands (Wood et al., 2002). Moreover, the livelihood-generating actions of poor communities near wetlands and their dependence on wetland resources have contributed to various degrees of degradation (Lamsal et al., 2017). Although Pulau Kukup is uninhabited by humans, a mere $1 \mathrm{~km}$ separates it from Kukup village, which comprises three major settlements - Kukup, Kampung Sungai and Kampung Air Masin (Hampton, 2010). Barau \& Stringer (2015) estimated the population of the Kukup fishing village to be around 1,000, with most inhabitants being Hokkien Chinese. According to Jaafar et al. (2014) and Lim et al. (2014), recent studies have revealed that water quality degradation due to urban and industrial use is threatening livelihoods and ecosystems around Pulau Kukup.

Andrade and Rhodes (2012) are of the opinion that the traditional approach of protection by prohibition through legislation and guarding is losing ground. Turner et al. (2000) added that underlying causes of degradation of wetlands are, among others, price distortions, income distribution inequalities, absence of full cost accounting, policy failure, market failure (missing price), lack of property rights and population/urbanization growth and consequent encroachment. However, Maltchik et al. (2018) emphasized that laws and legal statutes are crucial tools to protect and conserve wetland habitats, and how these laws are written and have important implications for wetland conservation. Ibrahim et al. (2012) said if these habitats and sites are protected by the enforcement of law, it will give more meaningful impacts to the people to find the subsistence for their life, and to make full use of natural resources. To date, limited studies have been conducted on the role of law in protecting wetlands in Malaysia, with most previous studies showing only the degradation of wetlands due to human intervention. Therefore, this study will show the crucial role of law in conserving and protecting wetlands in Malaysia. This paper will focus on the claim by the Sultan of Johor of the Pulau Kukup Johor National Park as sultanate land under section 2(1) of the Sultanate Land Enactment 1934 and how the law plays a role in protecting and conserving Pulau Kukup Johor National Park as a National Park of Johor.

\section{Materials, Methods and Study Area}

The primary aim of this study is to observe how the law has been implemented and amended to protect and conserve the Pulau Kukup Johor National Park in Malaysia. Qualitative methodology has been adopted in this study. In qualitative research, data are usually collected through three methods, either exclusively or in combination: direct observation, in-depth interviews and analysis of documents (May, 2001; Patton, 2002). To achieve the aims of this study, the researchers have focused on document analysis and studying text-based sources. Document analysis, ranging from the official to the personal, the text-based and image based, can provide a wealth of data (Webley, 2010). Documents reflect or report reality, describing an event, a perception, or an understanding (May, 2001). The mode of analysis depends on legislation as well as newspaper reports.

Pulau Kukup is located between $01^{\circ} 19^{\prime} \mathrm{N}$ and $103^{\circ} 25^{\prime} \mathrm{E}$ on the shores of southern Peninsular Malaysia's state of Johor. The total area of this mangrove island is $6.47 \mathrm{~km}^{2}$. Pulau Kukup offers physical protection to the shoreline and acts as a barrier against strong winds and tides for the low-density coastal settlement (Barau \& Stringer, 2015). Pulau Kukup was designated as Ramsar Site No. 1287 under the Ramsar Convention on $31^{\text {st }}$ January 2003 (Giesen et al., 2007). According to Johor National Parks (2019), there are three criteria that justified the Ramsar listing of Pulau Kukup. 
Pulau Kukup contains a representative, rare or unique example of a natural or near-natural wetland type found within the appropriate biogeographical region and it supports vulnerable, endangered, or critically endangered species or threatened ecological communities. In addition, it supports populations of plant and/ or animal species important for maintaining the biological diversity of a particular biogeographic region.

\section{Results and Discussion}

\section{Malaysia and Its Commitment to the Ramsar Convention}

Malaysia ratified the Ramsar Convention in 1994 (Ibrahim et al., 2012). Article 3(1) of the Ramsar Convention states that the contracting parties shall formulate and implement their planning so as to promote the conservation of wetlands included on the list. Each party shall promote the conservation of wetlands and waterfowl by establishing nature reserves on wetlands (Article 4(1)). Where a contracting party in its urgent national interest, deletes or restricts the boundaries of the wetland, it should compensate for any loss of wetland resources, and create additional nature reserves for waterfowl (Article 4 (2)). In addition, Article 4(4) encourages the contracting party to increase waterfowl population on appropriate wetlands. As a commitment to the Ramsar Convention, Malaysia has established seven Ramsar sites with a total area of $134,182.2$ hectares. The seven Ramsar sites are Tasek Bera, Tanjung Piai, Sungai Pulai, Pulau Kukup, Lower Kinabatangan-Segama Wetlands, Kuching Wetlands National Park and Kota Kinabalu Wetland. Details of these wetlands are as follows:

Table 1: Malaysia: Ramsar sites, dates and sizes (Ramsar, 2020)

\begin{tabular}{llr}
\hline \multicolumn{1}{c}{ Ramsar site } & \multicolumn{1}{c}{ Designated } & Size \\
\hline Kota Kinabalu Wetland & 22 October 2016 & 24.2 ha \\
Lower Kinabatangan-Segama Wetlands & 08 September 2008 & 78,803 ha \\
Kuching Wetland National Park & 08 November 2005 & 6,610 ha \\
Pulau Kukup & 31 January 2003 & 647 ha \\
Sungai Pulai & 31 January 2003 & 9, 126 ha \\
Tanjung Piai & 31 January 2003 ha \\
Tasek Bera & 10 November 1994 & 38,446 ha \\
\hline Total & & $134,182.2$ ha \\
\hline
\end{tabular}

The Division of Powers between Federal and State Governments in Malaysia

In Malaysia, the Federal Constitution is the supreme law of the land. However, its provision regarding environmental protection and the extent of responsibility between the federal and state government are vague. Land matters are under the jurisdiction of state governments, including forests and wetlands (Ibrahim et al. 2012). The National Policy of Wetlands has listed more than 60 federal and state laws that can be implemented for wetlands protection. One of the relevant statutes is the National Forestry
Act 1984, which is an important legislation for the Forestry Department. Other statutes include the National Park Act 1984 and, for endangered species, the Wildlife Conservation Act 2010 and the International Trade in Endangered Species Act 2008 (Ibrahim et al. 2012).

Article 73 of the Federal Constitution states that " in exercising the legislative powers conferred on it by this Constitution, (a) Parliament may make law for the whole or any part of the federation and law having effect outside as well as within the federation; and (b) the legislature of a state may of that state make 
laws for the whole or any part." Legislative jurisdiction of state and federal governments is based on Article 74, which shall be read together with the $9^{\text {th }}$ Schedule of the Constitution. Article 75 of the Federal Constitution states that if any state law is inconsistent with a federal law, the federal law shall prevail and the state law shall, to the extent of inconsistency, be void. In addition, Article 76 (1) of the Federal Constitution states that Parliament may make laws with respect to any matter enumerated in the State List, but only (a) for the purpose of implementing any treaty, agreement or convention between the Federation and any other country, or any decision of an international organization of which the Federation is a member. Meanwhile, Section 7 of the National Forestry Act 1984 states that a state government has the power to declare a forest area as Permanent Forest Reserve, while Section 34A of the Environmental Quality Act 1974 states that an environmental impact assessment is required for certain development projects.

\section{Jurisdiction of Pulau Kukup National Park, Johor}

In Malaysia, some laws are federal legislation while others are state enactments. Not all legislation will apply to the whole Peninsula, or to the states of Sabah and Sarawak. To provide for the establishment and control of National Parks and for matters connected herewith, the Federal National Parks Act (Act 226) was introduced in 1980 (Pakhriazad et al., 2009). This federal act shall not apply to national parks in three states - Taman Negara Pahang National Park, Taman Negara Kelantan National Park and Taman Negara Terengganu National Park. These three national parks have their own legislations - Taman Negara Enactment (Pahang) No.2 1939 [En.2 of 1938], Taman Negara Enactment (Kelantan) No.14, 1938 [En.14 of 1938] and Taman Negara Enactment Terengganu No.6, 1939 [En. 6 of 1358] (Pakhriazad et al., 2009). Since this is the constitutional position, constraints, especially on uniformity of laws, either to promote or enforce, particularly in respect to matters on List I - Federal List (Ninth Schedule of Article 74, 77 Legislative Lists), List II - State List (Article 95B(1)(a) and List III -Concurrent List (Article 95B (1)(b), often exist (Pakhriazad et al., 2009). Thus, there are some matters in which the National Parks fall under the legislative authority of both Federal and State governments. The act provides for states to establish National Parks to be administered by the Department of Wildlife and National Parks under the Federal Government. This act allows the State Authority to set aside land for the maintenance of roads, airstrips, reservoirs, dams and service buildings. However, forestry and land fall under the jurisdiction and legislative authority of the state in accordance with the Concurrent List of the Ninth Schedule (Pakhriazad et al., 2009). Despite the clear distribution of legislative power between the federal Parliament and State legislatures, there are still exceptional instances where Parliament can legislate on state matters. These exceptions will ensure that the Federal Government can be empowered to honour their covenants under international treaties or conventions (Talaat et al., 2013).

Pulau Kukup gained prominence in the 1990s when scientists began focusing on the island's biodiversity and unique ecological characteristics. In the interest of preserving this unique habitat, Pulau Kukup was gazetted as a National Park on 27 March 1997 under the Johor State Park Corporation Enactment 1989. On 31 January 2003, this island was granted the status of a "Wetland of International Importance" or RAMSAR Site, by the Geneva-based Ramsar Convention Bureau (Perbadanan Taman Negara Johor, 2020).

\section{Regazettement of Pulau Kukup as Johor National Park}

The crucial enactment involved when discussing the status of Pulau Kukup is the National Park (Johor) Corporation Enactment 1989. In section 3(1) of the National Park (Johor) Corporation Enactment 1989, it is stated that 'the State Authority may reserve any State land for the 
purpose of National Park', which implies that state authorities have the right to gazette and degazette any of its land as a National Park since land is under state legislative jurisdiction.

On 25 October 2018, a gazette was issued by the State of Johor to notify that the state authority will cancel Pulau Kukup as a National Park under subsection 3(3) of the National Park (Johor) Corporation Enactment 1989. The cancellation of the National Park gazettement status is to facilitate the land to be registered under the name of the Johor Ruler, Sultan Ibrahim Sultan Iskandar. The member of Parliament for Johor's Pasir Gudang district, Mr. Hassan Abdul Karim opposed the degazettement of Pulau Kukup and said, "without rectifying the status of Pulau Kukup as a National Park, the whole state executive council had committed omission for having failed to save the area as a Ramsar site in Malaysia (Malaysiakini, 2018)."

On 5 December 2018, the Crown Prince of Johor, Tunku Ismail Sultan Ibrahim, announced that Pulau Kukup will become Sultanate land under Schedule II of the Sultanate Land Enactment 1934 after the Johor state government had degazetted it from being a National Park. However, it is important to note that section 2(1) of the Sultanate Land Enactment 1934 provides that land held as Sultanate land is "not as part of the property of the State". Tunku Ismail claimed that Sultan Ibrahim Sultan Iskandar aimed to change the status of all the National Parks to Sultanate lands to ensure better protection and preservation for future generations (The Star, 2018a).

On 6 December 2018, the Johor state assembly approved an emergency motion declaring that the National Park status be maintained for environmental preservation regardless of the land status. Based on a letter dated 5 December 2018, which carried the signature of Johor Ruler, Sultan Ibrahim Sultan Iskandar, His Highness made clear his stance that Pulau Kukup's status as a National Park despite it being gazettes as Sultanate land. Pulau Kukup would be gazetted as a National Park according to Schedule II of the Sultanate Land Enactment 1934 (The Star, 2018b).

Interestingly, on 7 December 2018, the Federal Government interfered with the decision of Sultan Ibrahim. The Federal Government decided that Pulau Kukup would remain a National Park. The Minister of Water, Land and Natural Resources said the change in status of Pulau Kukup from National Park land to Sultanate land will have an effect on its recognition as an area of international interest as well as Malaysia's reputation as a country that prioritizes biodiversity. Any failure to manage this area can lead to the loss of priceless biodiversity (New Straits Times, 2018). On 9 December 2018, Tunku Ismail said only the Johor ruler has the jurisdiction to override the State Constitution. To rebut Tunku Ismail, the then-prime minister, Tun Dr Mahathir Mohamad said "Malaysians are not outsiders. The Federal Government is not an outsider. We are responsible for all things in the country. That is the stance of the Federal Government. Pulau Kukup should not be developed. It should remain as a forest reserve particularly as it is a special mangrove forest (The Star, 2018c)."

Finally, on 31 January 2019, Pulau Kukup's forest reserve status was restored according to the Johor state government gazette. The gazette states that the land will be reserved as Pulau Kukup National Park (Johor) as per the decision by the state government on 7 January 2019, with the state government invoking subsection 3(4) of the National Parks (Johor) Corporation Enactment 1989 (New Strait Times, 2019). The timeline of the degazettement and regazettement of Pulau Kukup can be summarised as follows: 
Table 2: Timeline of Pulau Kukup's degazettement and regazettement

\begin{tabular}{|c|c|}
\hline Date & Event \\
\hline 25 October 2018 & Degazettment of Pulau Kukup as a National Park. \\
\hline 5 December 2018 & $\begin{array}{l}\text { The Crown Prince of Johor, Tunku Ismail Sultan Ibrahim, announces that Pulau } \\
\text { Kukup to be made Sultanate land. } \\
\text { Letter dated } 5 \text { December } 2018 \text { signed by Sultan Ibrahim Sultan Iskandar saysPulau } \\
\text { Kukup's status is a National Park despite being made Sultanate land. }\end{array}$ \\
\hline 6 December 2018 & $\begin{array}{l}\text { Johor state assembly approves Pulau Kukup to remain a National Park regardless of } \\
\text { the land status. } \\
\text { Pulau Kukup to be gazetted as a National Park under Schedule II of the Sultanate } \\
\text { Land Enactment 1934. }\end{array}$ \\
\hline 7 December 2018 & Cabinet decides that Pulau Kukup remain a National Park. \\
\hline 9 December 2018 & $\begin{array}{l}\text { Tunku Ismail Pulau Kukup is under state jurisdiction and that the Federal Government } \\
\text { should not interfere with state matters. }\end{array}$ \\
\hline 31 January 2019 & $\begin{array}{l}\text { Based on the gazette dated } 7 \text { January } 2019 \text {, the status of Pulau Kukup as a a National } \\
\text { Park and under state jurisdiction has been restored. }\end{array}$ \\
\hline
\end{tabular}

From degazettement to regazettement of Pulau Kukup as a National Park, the researchers have identified two major issues that need further clarification. First, the jurisdiction of Pulau Kukup as forest and state National Park. According to Article 74 of the Federal Constitution, forests are under State List while National Parks are under the Concurrent List which involve both state and federal legislation. Both federal and state authorities have jurisdiction over matters which fall under the Concurrent List. Moreover, the National Parks Act 1980 allows states to establish National Parks to be administered by the Department of Wildlife and National Parks under the Federal Government. Section 3(1) of The National Park (Johor) Corporation Enactment 1989 states the power of State Authorities to reserve any state land as a National Park. However, Article 75 of the Federal Constitution needs to be taken into consideration whenever we discuss the Concurrent List of Federal and State jurisdiction. Article 75 of the Federal Constitution states that a federal law shall prevail over any inconsistent state law, and Article 76 grants the Federal Government the power to make laws under the State List for the purpose of implementing international treaties or conventions. Therefore, a decision by the Cabinet will prevail over the decision of a state ruler or legislature. Based on Article 75 and Article 76 of the Federal Constitution, the degazettement of Pulau Kukup is invalid since the Cabinet decided that Pulau Kukup's legal status should remain a National Park on 7 December 2018. It is also important to note that as a party to the Ramsar Convention, Malaysia is obligated to promote the conservation of wetlands.

The second issue is the status of Pulau Kukup as Sultanate land. Section 2(1) of the Sultanate Lands Enactment 1934 states that Sultanate land is not state land. Meanwhile, Section 3(1) National Park (Johor) Corporation Enactment 1989 states that the State Authority shall reserve any state land for the purpose of a National Park. This means that His Highness Sultan Ibrahim Sultan Iskandar's statement contradicts Section 3(1) of the National Park (Johor) Corporation Enactment 1989 because Sultanate land is not considered as a part of state land under Section 2(1) of the Sultanate Land Enactment 1934 and, therefore, cannot be gazetted as a National Park under the National Park (Johor) Corporation Enactment 1989. The 31 January 2019 gazette indicates Pulau Kukup still belongs to Johor State, which allows the state government to invoke subsection 3(4) National Park (Johor) Corporation Enactment 
1989 to regazette Pulau Kukup as a National Park.

\section{No more Environmental Impact Assessment on All Ramsar Sites in Malaysia}

Shortly after the controversial Pulau Kukup degazettement as National Park, the government of Malaysia has announced a total ban on environmental impact assessment on Ramsar sites in the country. Environmental impact assessments were introduced in 1988 as a measure of sustainability in development projects (Department of Environment, 2016) with development projects allowed at all Ramsar sites prior to 28 March 2019. Under Section 34 of the Environment Quality Act 1974, the project developer must take pollution prevention and control measures as a condition of environmental impact assessment approval to eliminate any threat to the ecosystem during the implementation of a project. In the event of damage or pollution during the development of the project, the developer will be liable for action under Section 34A of the Environment Quality Act 1974 and has to bear the costs of rehabilitating the area (Attorney-General's Chambers, 2006). However, on 28 March 2019, the then-Minister of Energy, Science, Technology, Environmental and Climate Change, Yeo Bee Yin, said in Parliament that the government will no longer approve environmental impact assessments on Ramsar sites to ensure the sustainability of these wetlands. She was replying to Kluang member of parliament Wong Shu Qi, who asked whether the government would approve development in the Ramsar site of Sungai Pulai in Johor (Bernama, 2019). Therefore, no development in Ramsar sites is allowed after 28 March 2019.

\section{Conclusion}

From the study, we find that legislation plays a crucial role in protecting and conserving wetlands in Malaysia. Regazettment of Pulau Kukup shows the role of legislation to protect and conserve wetlands in Malaysia. Strong legislation will ensure the sustainable development of wetlands in Malaysia. Although there is no doubt that other factors play important roles to conserve wetlands, such as public awareness and climate change, legislation is still the key factor to ensure the sustainability of wetlands. Although Malaysia does not have a comprehensive legislation to govern wetlands, the existing laws do comprehensively protect wetlands in the country. With the announcement from the Minister of Energy, Science, Technology, Environment and Climate Change that no environmental impact assessments are allowed on Ramsar sites, it is hoped Malaysian legislation will be the essential weapon to protect and conserve wetlands in Malaysia.

\section{Acknowledgements}

The authors extend their gratitude to reviewers for critical comments on the manuscript.

\section{References}

Andrade, G.S.M., \& Rhodes, J.R. (2012). Protected areas and local communities: an inevitable partnership towards successful conservation strategies? Ecology and Society 17(4), 14-23.

Attorney General Council. (2006). Environmental Quality Act 1974. The Commissioner of Law Division Malaysia.

Barau, A.S. \& Stringer, L.C. (2015). Access to and allocation of ecosystem services in Malaysia's Pulau Kukup Ramsar Site. Ecosystem Services 16: 167-173.

Bernama. (2019). No More Approval for EIAs on Ramsar Sites. Retrieved on 15 07, 2020 from https://www.freemalaysiatoday.com/ category/nation/2019/03/28/no-moreapproval-for-eias-on-ramsar-sites/.

Department of Environment. (2016). Environmental Impact Assessment Guideline 2016. Department of Environment, Malaysia.

Gibbs, J.P. (2011). Wetland loss and biodiversity conservation. Conservation Biology 14: 314-317. 
Giesen, W., Wulffraat, S., Zieren, M. \& Scholten, L. (2007). Mangrove Guidebook for Southeast Asia. FAO and Wetlands International.

Gopal, B. (2013). Future of wetlands in tropical and subtropical Asia, especially in the face of climate change. Aquatic Science 75: 3961.

Hampton, M.P. (2010). Enclaves and ethnic ties: the local impacts of Singaporean crossborder tourism in Malaysia and Indonesia. Singap. J. Trop. Geogr. 31(2): 239-253.

Ibrahim, I. Aziz, N.A \& Hanifah, N.A. (2012). The laws of wetness: The legislative framework in Malaysia regarding wetlands conservation. Social and Behavior Sciences 50: 574-581.

Jaafar, S.A., Latif, M.T., Chian, C.W., Han, W.S., Wahid, N.B., Razak, I.S., Khan, M.F. \& Tahir, N.M. (2014). Surfactants in the seasurface microlayer and atmospheric aerosol around the southern region of Peninsular Malaysia. Marine Pollution Bulletin 84: 35-43.

Johor National Parks. (2019). Ramsar Sites. Wetlands of International Importance. Retrieved on 15 07, 2020 from http://www. johornationalparks.gov.my/v3/ramsar-site/.

Junk W.J., An, S., Finlayson, C.M., Gopal, B., Kvet, J., Mitchell, S.A., Mitsch, W.J., \& Roberts, R.D. (2013). Current state of knowledge regarding the world's wetlands and their future under global climate change: A synthesis. Aquatic Sciences 75:151-167.

Keddy, P.A. (2010). Wetland Ecology: Principles and Conservation. Cambridge University Press.

Keddy, P.A., Fraser, I.H., Solomeshch, A.I., Junk, W.J., Ca,pbell, D.R., Arroyo, M.T.K., \& Alho, C.J.R. (2009). Wet and wonderful: The world's largest wetlands are conservation priorities. BioScience 59: $39-51$.
Lamsal, P., Atreya, K, Pant, K.P., \& Kumar, L. (2017) People's dependency on wetlands: South Asia perspective with emphasis on Nepal. Wetland Science: 407-419.

Lim, H.C., Leaw, C.P., Tan, T.H., Kon, N.F., Yek, L.H., Hii, K.S., Teng, S.T. (2014). A bloom of Karlodinium austral (Gymnodiniales, Dinophyceae) associated with mass mortality of cage-cultured fishes in West Johor Strait, Malaysia. Harmful Algae 40:51-62.

Malaysiakini. (2018). Pulau Kukup Degazetted in March 2018, Government Document Shows. Retrieved on 15 07, 2020 from https://www.malaysiakini.com/ news/454856.

Maltby, E., \& Acreman, M.C. (2011). Ecosystem services of wetlands: Pathfinder for a new paradigm. Hydrological Science Journal 56: 1341-1359.

Maltchik, L., Caleffi, V., Stenert, C., Batzer, D. P., Piedade, M.T.F \& Junk, W.J. (2018). Legislation for wetland conservation in Brazil: Are existing terms and definitions sufficient? Environmental Conservation 45: 301-305.

May, T. (2001). Social Research: Issues, Methods and Practices ( $2^{\text {nd }} E d$.). Buckingham: Open University Press.

New Strait Times. (2019). Pulau Kukup Now a Forest Reserve. Retrieved on 1507,2020 from https://www. pressreader.com/malaysia/new-straits-tim es/20190307/281625306609826.

New Straits Times. (2018). Cabinet: Pulau Kukup Must Remain a National Park. Retrieved on 15 07, 2020 from https://www. nst.com.my/news/nation/2018/12/438651/ cabinet-pulau-kukup-must-remainnational-park.

O'Connell, M.J. (2003). Detecting measuring and reversing changes to wetlands. Wetlands Ecology and Management 11(6):371-401. 
Pakhriazad, H.Z., Hasmadi, I.M., Aida, H.M.K. \& Jusoff, K. (2009). Historical and current legislations of Taman Negara National Park Penisular Malaysia. Journal of Politics and Law 2(1): 44-49.

Patton, M.Q. (2002). Qualitative Research and Evaluation Methods (3rd Ed.). London: Sage Publication.

Perbadanan Taman Negara Johor. (2020). Pulau Kukup. It's a World of Contrast, a Different Thing Altogether. Retrieved on 15 07, 2020 from https://www.johornationalparks.gov. my/v3/pulau-kukup/.

Ramsar. (2020). Ramsar Site Information Service. Retrieved on 15 07, 2020 from https://rsis.ramsar.org/rissearch/?f[0]=regionCountry_en $\mathrm{ss} \% 3$ AMalaysia\&pagetab $=1$.

Reis, V., Hermoso, V., Hamilton, Ward, D., Fluet-Chouinard, E., Lehner, B., \& Linke, S. A. (2017). Global assessment of inland wetland conservation status. BioScience 67(6): 523-533.

Talaat, W.I.A.W., Tahir, N.M., Rusli, M.H.M. \& Husain, M.L. (2013). The laws and policies for the sustainable management of biodiversity in Malaysia. Journal of Sus. Scie. and Manag. 8(2): 276-289.

The Star. (2018a). Pulau Kukup to Change from National Park to Sultanate Land, says TMJ. Retrieved on 15 07, 2020 from https://www. thestar.com.my/news/nation/2018/12/05/ pulau-kukup-to-change-from-nationalpark-to-sultanate-land-explains-tmj.

The Star. (2018b). Pulau Kukup to Keep National Park Status. Retrieved on 15 07, 2020 from https://www.thestar.com.my/ news/nation/2018/12/07/pulau-kukup-tokeep-national-park-status-johor-palaceconfirms-it-will-continue-to-be-protected/ .

The Star. (2018c) Dr. M Rebuts Johor Crown Prince, Says Federal Government Not 'Outsider' on Pulau Kukup. Retrieved on 15072020 from https://www.thestar.com. my/news/nation/2018/12/10/dr-m-rebutsjohor-crown-prince-says-federal-govt-notoutsider-on-pulau-kukup/.

Turner, R.K., Bergh, J.C.J.M., Barendregt, A. \& Malthy, E. (2000). Ecological-economic analysis of wetlands: Science and social science integration. Ecological Economics 35: 7-23.

Webley, L. (2010). Qualitative Approaches to Empirical Legal Research. In Cane, P. \& Kritzer, H. M. (Eds.) Oxford Handbook of Empirical Legal Research (pp.927-950). Oxford University Press.

Wood, A., Hailu, A., Abbot, P. \& Dixon, A. (2002). Sustainable management of wetlands in Ethiopia: Local knowledge versus government policy. Wetlands International Global Series 8, 81-88. 